\title{
Analysing motivation to do medicine cross-culturally: The international motivation to do medicine scale
}

\author{
Ma Ángeles Pastor ${ }^{1}$, Sofía López-Roig', Salvador Sánchez ${ }^{1}$, Jo Hart², \\ Marie Johnston ${ }^{3}$, Diane Dixon ${ }^{4}$ \\ ${ }^{1}$ Universidad Miguel Hernandez, España, ${ }^{2}$ University of Manchester, UK, \\ ${ }^{3}$ University of Aberdeen, UK, ${ }^{4}$ University of Stirling, UK \\ Disponible online 30 de abril de 2009
}

\begin{abstract}
Vaglum, Wiers-Jensen, \& Ekeberg (1999) desarrollaron una escala para evaluar la motivación para estudiar Medicina. La escala ha sido utilizada en diferentes países pero no se ha trabajado transculturalmente. El objetivo de este estudio es desarrollarla para su uso internacional y comparar la motivación para estudiar Medicina de estudiantes británicos $(n=375)$ y españoles $(n=149)$. Se planteó un estudio transversal y transcultural. Utilizando el Análisis Factorial Confirmatorio no se pudo confirmar la estructura trifactorial obtenida por Vaglum et al. (1999) en ninguna de las dos muestras. Los resultados del Análisis Factorial exploratorio con las muestras de cada país mostraron la existencia de cuatro factores: "Personas", "Estatus", “Ciencias Naturales" e "Investigación”. Los estudiantes puntuaron significativamente más alto en "Personas" y "Ciencias Naturales". Los estudiantes británicos puntuaron significativamente más alto que los españoles en el factor "Investigación" y se obtuvo diferencias mayores entre géneros en la muestra española para los factores "Personas" e "Investigación". La escala es apropiada para evaluar la motivación para hacer medicina transculturalmente; puede utilizarse para investigar diferencias entre países y para evaluar cambios motivacionales en el tiempo o entre diferentes especialidades médicas.
\end{abstract}

Palabras clave:

Motivación, estudiantes de Medicina, estudio transcultural.

Vaglum, Wiers-Jensen, \& Ekeberg (1999) developed an instrument to assess motivation to study medicine. This instrument has been applied in different countries but it has not been studied cross-culturally. Our aims were to develop a Motivation to do Medicine Scale for use in international studies and to compare motivations of UK and Spanish medical students (UK: $n=375$; Spain: $n=149$ ). A cross-sectional and cross-cultural study was conducted. The Vaglum et al. (1999) Motivation to do Medicine Scale (MMS) was used. The original MMS factor structure was not supported by the Confirmatory Factor Analysis. Exploratory Factor Analyses within each country identified four factors: "People", "Status", "Natural Science" and "Research". Students scored higher on the "People" and "Natural Science" than on the other factors. The UK sample scored higher than the Spanish sample on the "Research" factor and there were greater difference between genders in Spain for both "People" and "Research" factors. The scale is suitable for use in cross-cultural studies of medical students' motivation. It can be used to investigate differences between countries and may be used to examine changes in motivation over time or over medical disciplines.

Keywords:

Motivation, medical students, cross-cultural study.

\footnotetext{
$\mathrm{M}^{\mathrm{a}}$ Ángeles Pastor and Sofía López-Roig have been supported by a grant stage from Ministerio Educación, Cultura y Deporte from Spain (Programa Salvador de Madariaga, 2005).

Jo Hart was supported by a Research Studentship from the Universities of St. Andrews and Aberdeen.

Correspondence should be addressed to $\mathrm{M}^{\mathrm{a}}$ Ángeles Pastor, Universidad Miguel Hernández; Dpto. Psicología de la Salud; Ctra. Alicante-Valencia s/n, Km.87; Sant Joan d'Alacant. E-03550 (Spain). Phone: (+34) 9659194 70. Fax: (+34) 9659194 75. E-mail: mapastor@umh.es
} 
Motivation is an important psychological factor which influences our choices. Research has shown that different kinds of motivators are associated with different behavioural outcomes (González, Valle, Núñez, \& González-Pienda, 1996; Williams, Saizow, \& Ryan, 1999) Some studies have examined this construct in an undergraduate medical context, as a predictor of career choice (Crossley \& Mubarik, 2002), academic learning and achievement (Sobral, 2004) and medical specialty preferences (Vaglum, Wiers-Jensen, \& Ekeberg, 1999).

Vaglum et al. (1999) found three different motivation factors for studying medicine ("People", "Status/Security" and "Natural Science") that were related to the medicine speciality chosen by students (Vaglum et al., 1999; Wierenga, Branday, Simeon, Pottinger, \& Brathwaite, 2003). A career in medicine provides the opportunity to work with people. As part of their training, students learn the behavioural, psychological and social aspects of illness, aspects of treatment adherence and how to interact with patients and families. We can classify all of these as the behavioural, psychological and social content of the doctor's role. This is especially important for those students who want to conduct clinical work, and it is possible that motivation is also related to their attitude towards these aspects of the role. We might expect that different motivations to become a doctor could influence priorities in patient care. In fact, in a UK group of medical students, the "Natural Science" factor was significantly and negatively associated with intention to give patients health behaviour advice (Hart \& Johnston, 2004).

Vaglum et al. (1999) tested Norwegian medicine students' motivation and developed an instrument to assess motivation to study medicine (Motivation to do Medicine Scale, MMS). Because motivation might be influencing several aspects of medical students' behaviour and attitudes, it is useful to examine the MMS's psychometric properties in more detail and to replicate its factor structure cross-culturally. For future research, this would enable comparison between different countries.

Motivation may be a function of individual or situational differences (González et al., 1996; Perrot, Deloney, Hastings, Savell, \& Savidge, 2001). Country is a key factor in situational differences, including training, health, disease patterns and patients lifestyle. Several studies have shown that women score higher in traits such as helpfulness, empathy, family responsibility and job security, whereas men score higher on independence, decisiveness, self-confidence, activity, income and prestige (Buddeberg-Fischer, Klaghofer, Abel, \& Buddeberg, 2003). Therefore, gender might be related to differences in motivation as women are considered as more people oriented and men as more instrumental. Finally, in the Vaglum et al. (1999) study, having a father who was a doctor was not associated with motivation to do medicine, but it might be a relevant factor in other samples.

In the framework of a wider cross-cultural follow-up investigation with medical students about their intention to give health behaviour advice and its determinants, the role of motivational factors to do medicine was studied. The present study tried to answer the following questions in relation to motivation:

a) Is it possible to replicate the three factor structure of the Motivation to do Medicine Scale obtained by Vaglum et al. (1999) with medical students from two different European countries (UK and Spain)?

b) Do motivations differ as a function of socio-demographic variables?

\section{Methods}

\section{Participants}

375 UK medical students, in their $1^{\text {st }}$ year at St. Andrews and Manchester Universities; and 149 Spanish students at the beginning of their $2^{\text {nd }}$ year at Miguel Hernandez University.

In the UK sample, $43.10 \%$ of the students were male and the average age was 18.92 years $(S D=2.16$; range $=17-36)$. In the Spanish sample, $22.10 \%$ of the students were male. The average age was 19.13 years $(S D=0.87$; range $=18-26)$. The gender balance in each sample reflects the gender balance of the medical students in their respective countries. Finally, in both samples, parents of the majority of the medical student worked in non-medical professions (UK: 68.40\%; Spain: 77.80\%).

\section{Design and Procedure}

All the self-report measures were administered in a classroom setting. Students attending classes were invited to participate. The purpose of the study was briefly explained before they were provided with an information sheet and consent form. Of the students registered for that subject, $92.84 \%$ of the UK students and $66 \%$ of the Spanish students took part in the study. Nobody attending the class refused to participate.

In the Spanish sample, the administration of the MMS was repeated seven months later to assess the test-retest reliability.

\section{Measures}

Motivation to do Medicine Scale (MMS). Vaglum et al. (1999) categorized motivations into three factors: "Status/ Security orientation" (6 items), "Altruistic/People orientation" (3 items) and "Interest in Natural Sciences" (3 items). The MMS asks people to what extent each item was important in their decision to study medicine (with responses from $0=$ not at all, to $3=$ strongly decisive). For this study, the response mode ranged from $1=$ not at all important, to $5=$ is very important.

Vaglum's et al. MMS (1999) was translated and backtranslated into Spanish by bi-lingual English-Spanish language professionals. In addition, the English authors of this paper compared the translated version with the 
original, to ensure that the items of both versions had the same meaning (Appendix 1).

\section{Data analysis}

Descriptive and Chi-squared analyses were conducted to establish whether the samples significantly differed in their socio-demographic characteristics.

A Confirmatory Factor Analysis (CFA) was conducted in order to test the three factor structure of the MMS (Vaglum et al., 1999). Data were analysed with the EQS (6.1) software package (Bentler, 2004). Factor variances were set to one to identify the model and to enable the factor loading coefficients of each item to be estimated. The factors were free to co-vary. Each dataset was analysed separately and covariance matrices were the basis of the model estimation throughout the maximum likelihood method (Satorra \& Bentler, 1994). Four fit indices were used: $\chi^{2}$, NNFI (non-normed fit index), CFI (comparative fit index) and RMSEA (root mean square error of approximation) (Bearden, Sharma, \& Teel, 1982; Browne \& Cudeck, 1993; Hu \& Bentler, 1995, 1996).

An Exploratory Factor Analysis (EFA) using principal component analysis with Varimax rotation was also carried out following the original author's criteria (Vaglum et al., 1999). Cronbach's alpha was used to assess the internal consistency and Pearson correlation to assess test-retest reliability.

Repeated Measures ANOVA was carried out to explore differences on motivation factors between countries and to investigate whether socio-demographic variables introduced differences in motivational factors obtained in each country.

All results were considered at .01 level of significance. SPSS14.0. was used to conduct statistics except for the CFA.

\section{Results}

A CFA was performed to test the fit of the data to the measurement model generated by the Vaglum's EFA. Table 1 shows the goodness of fit indexes for both samples. As it can be observed, the fit was not adequate (Table 1).

Table 1. Confirmatory Factor Analysis of the Motivation to do Medicine Scale. Goodness of Fit Indixes a

\begin{tabular}{|c|c|c|c|c|}
\hline Samples & $\chi^{2}(d f) p$ & NNFI & CFI & $\begin{array}{c}\text { RMSEA } \\
\text { (90\% C.I.) }\end{array}$ \\
\hline UK & $163.50(51) .001$ & .79 & .84 & $\begin{array}{c}.08 \\
(.06, .09)\end{array}$ \\
\hline Spanish & $124.3(51) .001$ & .75 & .81 & $\begin{array}{c}.10 \\
(.08, .12)\end{array}$ \\
\hline
\end{tabular}

An EFA was conducted in each sample. A similar pattern across both samples was found. Four factors were very similar factors and one additional factor was found in the UK sample. The UK factor which was not found in the Spanish sample, had an eigen value of 1.03 which is, following the Kaiser method, a marginal value. Further, since the items did not make theoretical sense, it could not be used in cross-cultural investigations and was excluded from further consideration (Table 2).

Table 2. Motivation to do Medicine Scale. Exploratory Factor Analyses and factor loadings.

\begin{tabular}{|c|c|c|c|}
\hline Items & $\begin{array}{c}\text { UK } \\
(52.43 \%)^{a}\end{array}$ & $\begin{array}{l}\text { SPANISH } \\
(60.04 \%)\end{array}$ & $\begin{array}{l}\text { VAGLUM'S } \\
\text { STUDY }\end{array}$ \\
\hline Status/Security & $(21.80 \%)$ & $(22.72 \%)$ & \\
\hline 1. Opportunity for high income & .77 & .85 & .74 \\
\hline 2. Social prestige/status & .76 & .79 & .65 \\
\hline 3. Job security & .67 & .80 & .69 \\
\hline $\begin{array}{l}\text { 4. The education leads to a defined } \\
\text { profession }\end{array}$ & .71 & .67 & .68 \\
\hline $\begin{array}{l}\text { 6. Opportunity to take advantage of } \\
\text { good grades }\end{array}$ & .55 & .52 & \\
\hline 5. Classroom-like study programme ${ }^{b}$ & & & .58 \\
\hline People & $(13.21 \%)$ & $(17.51 \%)$ & \\
\hline $\begin{array}{l}\text { 7. Being a doctor provides opportunity } \\
\text { for social and humanitarian effort }\end{array}$ & .77 & & \\
\hline 8. Opportunity to work with people & .17 & .82 & .78 \\
\hline 9. Opportunity to care for people & .71 & .85 & .79 \\
\hline $\begin{array}{l}\text { 10. Interest in relations between } \\
\text { health, well-being and society }\end{array}$ & & .61 & \\
\hline Natural Sciences & $(8.39 \%)$ & $(10.58 \%)$ & \\
\hline 12. Interest in human biology & .73 & .88 & .66 \\
\hline 14. General interest in natural science & .84 & .75 & .73 \\
\hline 13. Opportunity to perfom research & & & .61 \\
\hline Research & $(9.03 \%)$ & $(9.22 \%)$ & \\
\hline $\begin{array}{l}\text { 6. Opportunity to take advantage of } \\
\text { good grades }\end{array}$ & & .53 & \\
\hline 11. Desire for challenge & .68 & .67 & \\
\hline 13. Opportunity to perform research & .75 & .69 & \\
\hline
\end{tabular}

a explained variance into brackets; ${ }^{b}$ in cursive items loading only in the original study.

The items were allocated to each factor using a cut-off of .50 for factor loadings as in the Vaglum's study. Three factors are close to those obtained in the original scale: "Status/ Security" (Factor I) "People" (Factor II) and "Natural Sciences" (Factor III in the Spanish sample and Factor IV in the UK sample). The fourth factor was also very similar between the two samples and was named "Research".

Three factors similar to those of Vaglum et al. (1999) were found although there were differences in the number of items.

In order to get a measure suitable for cross-cultural studies (International MMS: IMMS), the items common to the factors found in all the three countries were selected. The items with the lowest loadings on their respective factors were excluded. In addition, the Research factor was included for further exploration.

Alpha and test-retest coefficients ranged from .41 for "Research" in the UK sample to .81 for "Status/Security" in the Spanish sample (Table 3). 
Table 3. International Motivation to do Medicine Scale. Reliability analysis.

\begin{tabular}{lccccc}
\hline Factors & $\begin{array}{c}\text { Number } \\
\text { of items }\end{array}$ & UK & \multicolumn{2}{c}{ SPAIN } \\
Status/Security & $4(1$ to 4$)$ & .76 & .81 & $.74^{*}$ \\
People & $2(7 / 9)$ & .52 & .70 & $.73^{*}$ \\
Natural Science & $2(12 / 14)$ & .49 & .64 & $.61^{*}$ \\
Research & $2(11 / 13)$ & .41 & .46 & $.57^{*}$ \\
\hline
\end{tabular}

Factor scores were calculated and only three significant correlations were found: In UK, "Status/Security" correlated with "Natural Science" ( $r=.21, p \leq .01)$; in Spain, "Research" correlated with "Natural Science" $(r=.24, p \leq .01)$ and with "Status/Security" ( $r=.30, p \leq .01)$. Values were low. Results showed that factors are independent of each other. Descriptive data for each factor are shown in table 4.

Table 4. International Motivation to do Medicine Scale. Mean factor scores.

\begin{tabular}{lcccc}
\hline Samples & $\begin{array}{c}\text { Status/ } \\
\text { Security }\end{array}$ & People & Science & Research \\
UK total & $2.79 \pm 0.87$ & $4.20 \pm 0.71$ & $4.06 \pm 0.65$ & $3.78 \pm 0.76$ \\
Male & $2.91 \pm 0.87$ & $4.13 \pm 0.74$ & $3.99 \pm 0.68$ & $3.70 \pm 0.77$ \\
Female & $2.70 \pm 0.86$ & $4.25 \pm 0.68$ & $4.12 \pm 0.62$ & $3.86 \pm 0.75$ \\
& & & & \\
Spanish total & $2.63 \pm 0.92$ & $4.33 \pm 0.78$ & $4.06 \pm 0.81$ & $3.21 \pm 1.07$ \\
Male & $2.94 \pm 0.94$ & $3.90 \pm 1.00$ & $4.21 \pm 0.88$ & $3.47 \pm 1.09$ \\
Female & $2.54 \pm 0.90$ & $4.45 \pm 0.66$ & $4.01 \pm 0.79$ & $3.14 \pm 1.06$ \\
\hline
\end{tabular}

The Repeated Measures ANOVA showed a main effect of the motivation factor $(F(3,519)=370.08, p \leq .001)$ with "People" and "Natural Science" scoring higher than the other two factors. The ANOVA also showed an interaction effect of motivation $\mathrm{x}$ country $(F=17.64, p \leq .001)$. Post-hoc comparisons with Bonferroni correction showed significant differences between countries only in the "Research" factor $(F(3,519)=337.34$, $p \leq .001)$.

The subsequent ANOVAs testing the effects of socio-demographic variables and country in each IMMS motivation factor showed:

A main effect of gender in "Status/Security" $(F(1,518)=$ $9.51, p \leq .002)$ and "People" factors $(F(1,518)=16.77, p \leq .001)$. Men scored higher in "Status/Security" and women in "People". Interaction effects of gender $\mathrm{x}$ country were obtained in "People" $(F(1,518)=7.14, p \leq .008)$ and "Research" $(F(1,518)=$ $6.23, p \leq .01$ ) (Figure 1).
Figure 1. Gender by Country.

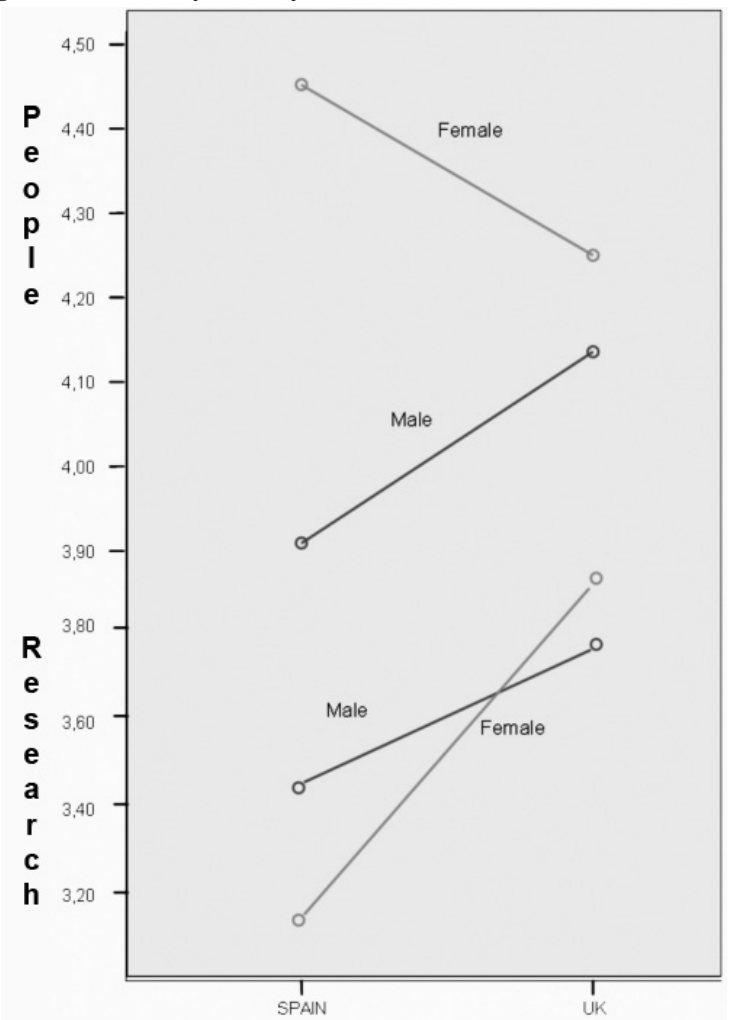

Significant differences between Spanish males and females was found in "People" factor $(F(1,518)=14.65, p \leq .001)$. No significant differences were found between UK male and female students. UK female students scored lower than Spanish female in the "People" factor $(F(1,518)=5.90, p \leq .01)$ and higher in "Research" $(F(1,518)=50.93, p \leq .001)$.

An interaction effect was found on "Research" factor for "Country x Some parent health professional" $(F(1,505)=$ $7.95, p \leq .005$ ) (Figure 2). Spanish students with one or more parent being a health professional scored lower on Research factor $(F=8.71, p \leq .003)$ while in UK parental profession did not affect scores on this factor.

Figure 2. At least one parent health professional x Country on Research.

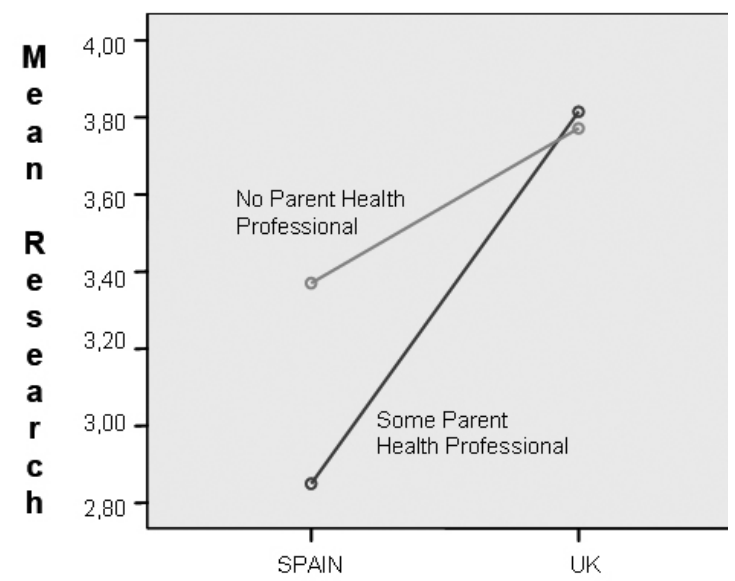


Discussion

The first aim of this work was to replicate, in UK and Spanish students, the motivational factor structure for doing medicine obtained by Vaglum et al. (1999) with Norwegian students. Results of the CFA in our samples did not support the original three factor structure. However, subsequent EFA showed a very similar factor structure in both the UK and Spain which explained an adequate amount of variance in both cases. For three factors, this structure was close to that obtained in the original study (Vaglum et al., 1999).

In both countries, the three main factors of Vaglum et al. (1999) were found although the numbers of items were different. In relation to "Status/Security", the item 5 ("Classroomlike study program") dropped out in both our samples, perhaps because of a different model of teaching to the Norwegian one. For "Natural Science", item 13 ("Opportunity to perform research") dropped out in both samples; it was the item with the highest loading in an additional factor that was named "Research". Besides the item 13, the item 11 ("Desire for challenge") conformed this new factor in both samples.

In order to get a motivational measure suitable for crosscultural comparisons, only the items which had a significant loading in the three samples were retained. The result was a common measure made up ten items, only four items less than the original scale. Three factors similar to those of the original instrument and an additional factor ("Research") were included. Therefore, the final scale that is proposed for use in crosscultural studies is made up three subscales: "Status/Security" (four items); "People" (two items) and "Natural Science" (two items). The new subscale "Research" (two items) could be used in UK and Spanish studies.

The internal consistency of some of the subscales should be improved, especially in the UK sample. In both samples, the lowest internal consistency was for the factors "Natural Science" and "Research" whose item wording is more general, compared with the other subscale items. To ascertain how items are being interpreted within the factors, it might be useful to test the meaning of items, especially those showing low loadings.

MMS (Vaglum et al., 1999) is a short assessment tool about motivation which includes a broad field of motivators to study medicine. The current study extends the original instrument and offers a cross-cultural measure of this construct. Using the IMMS, motivations to begin medicine could be compared across countries but it also will allow studying the influence of motivation in career development or future professional role behaviour.

A motivational structure which includes the four above mentioned factors has been obtained in two different countries, as independent factors. The main differences with the original structure are the number of items of each factor and the new factor, "Research", as an independent motive to study medicine. This factor could be related to the possible change in the importance of social knowledge of research over time since Vaglum et al.'s (1999) study, for example the trend towards evidencebased medicine, or it might reflect true cultural differences.

"Research" was the only factor in which the current samples scored differently; UK students were higher in their interest in research as a motive to study medicine. This result could reflect cultural differences about the importance of research in each country. Apart from "Research", students from the two countries were quite similar in relation to their main motivators to do medicine. There are considerable similarities over countries, "People" was the main motive to do medicine, followed by "Natural Science", "Research" and, finally, by "Status/Security". These data are consistent with those obtained for other authors (Crossley \& Mubarik, 2002; Vaglum et al., 1999; Wierenga et al., 2003). The high and stable cross cultural interest for "People" in those who wish to study medicine could have some implications for future professional and clinical practice. It would be interesting to conduct follow up studies to assess changes over time. Does this motivation decrease over time and with progress through academic courses and other biological or status motives become more important? In addition, do students' scores predict their behaviours?; for example, do students who score high in the "People" factor have better relationships with their patients than students who score low on this factor?

A very similar pattern of gender differences was also found between the UK and Spain samples, despite the different proportions of men and women studying medicine in the two countries. Women's and men's motivations to do medicine showed the general cultural orientation attributed to them. In both countries the most important motives to do medicine for women were related to a people orientation. Men in both countries scored higher than women in motivations related to high income or social status. These results are only consistent with Vaglum et al. (1999) for the first mentioned difference. In their study, Norwegian women were not significantly different to men in high income/social status motives and they also showed stronger interest in human biology and desire for challenges than men. However our results are similar to those obtained by other authors with Swiss and Indian medical students (Buddeberg-Fischer et al., 2003; Wierenga et al., 2003). BuddebergFischer et al. (2003) studied personality traits, career motivation and career planning and they found women scored higher in traits related to a people orientation.

Two interaction gender $\mathrm{x}$ country effects were found. The main differences were found between Spanish males and females and between females from the two countries. Spanish women were higher than Spanish men and than UK women in "People" and lower than UK women in "Research" motives. No significant differences between UK and Spanish males or between UK men and women were found. These results may reflect a cultural bias for Spanish women. Caring for others is an important traditional role for Spanish women and may well influence their work preferences. 
As in Vaglum et al. (1999) study, having a father who is a physician did not influence the motivation pattern. However, one effect was obtained if at least one parent was a health professional: Spanish students with a parent health professional scored lower in the "Research" factor than the others, while there was no difference for the UK students.

This study has some limitations: the samples of this study were limited to students who attended class at the testing time. Because the measures were administered in a lecture of social and behavioural sciences, these students might have been biased to a "People" orientation motive. However, this seems unlikely as over $90 \%$ of the possible the UK sample was obtained and no difference was found between the UK and the Spanish samples on this factor. Further, low internal consistency of some scales could affect the stability of the results. But, in general, our results are consistent with those obtained by other authors in other conditions and countries.

In conclusion, a relatively stable cross-cultural motivational structure in medical students was found using the adaptation of the Vaglum's et al. scale (1999). In general, the most important motives to be a doctor were consistent. Future cross-cultural studies could usefully use the ten items version resulting from this study. For future research, it would be interesting to test the four motivational factor solution using Confirmatory Factor Analysis approach. It would also be necessary to work to improve the internal consistency of some subscales. Finally, future implications of these four motivators could be studied. For instance, how motivation influences the student's practice performance, how motivation changes on becoming a doctor or how specific motivators can influence different kinds of medical practice.

\section{Appendix 1}

International Motivation to do Medicine Scale (IMMS).

Studying medicine (UK version)

On a scale of 1 to 5 , If 1 is not at all important and 5 is very important, how much importance do you place on each of the following reasons for studying medicine:

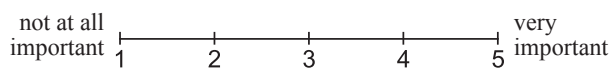

\begin{tabular}{|c|l|c|}
\hline 1 & Opportunity for high income & \\
\hline 2 & Social prestige/status & \\
\hline 3 & Job security & \\
\hline 4 & The education leads to a defined profession & \\
\hline 7 & $\begin{array}{l}\text { Being a doctor provides opportunity for social and humanitarian } \\
\text { effort }\end{array}$ & \\
\hline 9 & Opportunity to care for people & \\
\hline 11 & Desire for challenge & \\
\hline 12 & Interest in human biology & \\
\hline 13 & Opportunity to perform research & \\
\hline 14 & General interest in natural science & \\
\hline
\end{tabular}

Estudiar Medicina (Spanish version).

En una escala del 1 al 5, si 1 es "nada importante" y 5 es "muy importante", ¿qué importancia da a cada una de las siguientes razones en su decisión de estudiar medicina?

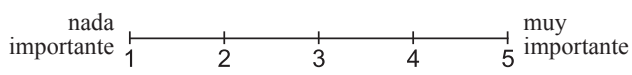

\begin{tabular}{|c|l|c|}
\hline 1 & Oportunidad de ganar un sueldo elevado & \\
\hline 2 & Prestigio social/Estatus & \\
\hline 3 & Trabajo seguro & \\
\hline 4 & La carrera tiene salidas profesionales muy definidas & $\begin{array}{l}\text { Ser médico ofrece la oportunidad de realizar acciones sociales y } \\
\text { humanitarias }\end{array}$ \\
\hline 9 & Oportunidad de cuidar a la gente & \\
\hline 11 & Deseo de plantearme un desafío & \\
\hline 12 & Interés en la biología humana & \\
\hline 13 & Oportunidad de llevar a cabo investigaciones & \\
\hline 14 & Interés general en las Ciencias de la Naturaleza & \\
\hline
\end{tabular}

\section{References}

Bearden, W.O., Sharma, S., \& Teel, J.E. (1982) Sample-Size Effects on Chi-Square and Other Statistics Used in Evaluating Causal-Models. Journal of Marketing Research, 19, 425-30.

Bentler, P.M. (2004). EQS 6 Structural Equations Program Manual. Encino, CA: Multivariate Software.

Browne, M.W., \& Cudeck, R. (1993). Alternative ways of assessing model fit. Beverly Hills: C.A. Sage.

Buddeberg-Fischer, B., Klaghofer, R., Abel, T., \& Buddeberg, C. (2003). The influence of gender and personality traits on the career planning of Swiss medical students. Swiss Medical Weekly, 133, 535-40.

Crossley, M.L., \& Mubarik, A. (2002). A comparative investigation of dental and medical student's motivation towards career choice. British Dental Journal, 193, 471-473.

González, R., Valle, A., Núñez, J., \& González-Pienda J. (1996). Una aproximación teórica al concepto de metas académicas y su relación con la motivación escolar. Psicothema, 8, 45-61.

Hart, J., \& Johnston, M. (2004). Effect of medical education on medical students' attitudes towards giving health behaviour advice. Proceedings of the International Congress of Behavioral Medicine, August, Mainz, Germany.

Hu, L., \& Bentler, P.M. (1995). Evaluating Model Fit. Newbury Park, C.A.: Sage.

Hu, L., \& Bentler, P.M. (1999). Cut-off criteria for fit indexes in covariance structure analysis: conventional criteria versus new alternatives. Structural Equation Modelling, 6, 1-55. 
Perrot, L.J., Deloney, L.A., Hastings, J.K., Savell, S., \& Savidge, M. (2001). Measuring student motivation in health professions' colleges. Advances in Health Science Education Theory and Practice, 6, 193-203.

Satorra, A., \& Bentler, P.M. (1994). Corrections to test statistics and standard errors in covariance structure analysis. London: Sage.

Sobral, D.T. (2004). What kind of motivation drives medical students' learning quests?. Medical Education, 38, 950-7.

Vaglum, P., Wiers-Jensen, J., \& Ekeberg, Ø. (1999). Motivation for medical school: the relationship to gender and specialty preferences in a nationwide sample. Medical Education, 33, 236-42.

Wierenga, A.R., Branday, J.M., Simeon, D.T., Pottinger, A., \& Brathwaite, B. (2003). Motivation for and concerns about entering a medical programme. West Indian Medical Journal, 52, 304-10.
Williams, G.C., Saizow, R.B., \& Ryan, R.M. (1999). The importance of self-determination theory for medical education. Academic Medicine, 74, 992-5.

\section{Author notes}

Authors are very grateful to J. Wiers-Jensen for her useful comments and to students and staff of the Universities of St. Andrews, Aberdeen and Miguel Hernández for the participation in this study.
Fecha de recepción: 4 de marzo de 2009 Fecha de aceptación: 16 de marzo de 2009 